\title{
HEMATOLOGICAL CHANGES ASSOCIATED WITH MIXED INFECTION OF COCCIDIOSSIS AND NECROTIC ENTERITIS IN TURKEY
}

\author{
DOAA I.A. MOSTAFA ${ }^{1}$ AND SANAA M SALEM ${ }^{2}$ \\ ${ }^{1}$ Department of Clinical Pathology, Animal Health Research Institute (AHRI), Zagazig Branch, \\ Agriculture Research Center (ARC), Egypt. \\ ${ }^{2}$ Department of Pathology, Animal Health Research Institute (AHRI), Zagazig Branch, Agriculture \\ Research Center (ARC), Egypt.
}

Received: 30 October 2020; Accepted: 10 November 2020

\begin{abstract}
Necrotic enteritis is a significant problem to the poultry industry all over the world. Little information exists concerning the pathogenesis, immunity or experimental induction of necrotic enteritis in turkeys. Therefore, the present work was designed to develop an experimental model of coccidiosis and necrotic enteritis in turkey for detection of the hematological changes associated with it with trial to overcome using amoxicillin and diclazuril. 40 one day old turkey poults were used for this, divided randomly into 4 equal groups. Gp. (1) left as normal control, gps. (2, 3 and 4) infected experimentally with Eimeria spp, Clostridium perfringens and mixed infection respectively and treatment of groups 2, 3, and 4 by amoxicillin, diclazuril and (amoxicillin+diclazuril) respectively by the appearance of symptoms. The study revealed anemia in gps. 2, 3 and 4, with increase in the platelets count in gps. 2 and 4 and increase in the RBCs osmotic fragility in gps. 3 and 4. In addition to, increase in the total and differential leucocytic count in all infected gps. The amoxicillin and diclazuril had significant improvement in all associated changes.
\end{abstract}

Keywords: Clostridium perfringens- Eimeria spp- Turkey - Hematogical changes- Osmotic fragility

\section{INTRODUCTION}

Turkey is important poultry species grown in Egypt and of high economic importance, but their industry exposing many problems. Necrotic Enteritis (NE) and Coccidiosis are widespread diseases of considerable economic importance affecting the turkey industry, as it causes high losses among birds in addition to the high cost of its control. It is caused by

Corresponding author: Doaa I.A. Mostafa

E-mail address: doaaibrahim706@gmail.com

Present address: Department of Clinical Pathology,

Animal Health Research Institute (AHRI), Zagazig

Branch, Agriculture Research Center (ARC), Egypt. mixed infection of both Clostridium perfringens and Eimeria spp. (Timbermont et al., 2011). Avian necrotic enteritis was first described in 1961 (Parish, 1961) and since then it has been reported to occur in almost poultry-producing countries (Mcdevit et al., 2006).

Clostridium perfringens is a gram-positive, rod-shaped, spore-forming, anaerobic bacterium. It is commonly found as a normal inhabitant of the gastrointestinal tract of humans and animals (Fasina et al., 2016).

It produces at least 12 different toxins, which are associated with the occurrence of 
the disease. Not all the $C$. perfringens inhabiting the gut are pathogenic, only few strains are virulent and pathogenic. They produce extracellular toxin types, named; alpha $(\alpha)$, beta $(\beta)$, epsilon $(\varepsilon)$, and iota (i). They produced by $C$. perfringens biotypes $\mathrm{A}, \mathrm{B}, \mathrm{C}, \mathrm{D}$, and $\mathrm{E}$ (Paiva and McElroy 2014). The $\alpha$-toxin was the major toxin involved in necrotic enteritis in poultry (Timbermont et al., 2009).

The disease result in outbreaks with mortality rates reached to $50 \%$ as an acute enterotoxaemia. The clinical signs are usually of rapid onset, and often represented by severe depression followed by a sudden increase in flock mortality. The disease primarily affects broiler chickens at 2-5 weeks old and turkeys at 7-12 weeks old (Osman and Elhariri, 2013). For many years, prophylactic use of antibiotic in feed has been primary practice for controlling necrotic enteritis in broiler industry, however it may develop $C$. perfringens strain resistance antibiotic which may threatened economic stability of broiler industry (Baumgartner, 2003). Amoxicillin was most effective against $81.8 \%$ of tested isolates of $C$. perfringens isolated from turkey and had significant improvement of turkey infected cases (Sanaa et al., 2020).

Coccidiosis is the most common predisposing factors of NE (Paiva and McElroy 2014). It is an important disease of the turkey caused by protozoan parasites of the genus Eimeria. The parasites are widespread in turkey flocks and capable of causing considerable economic loss yet, compared with the chicken, little research has been undertaken to better our understanding of the disease and develop improved methods of control (Chapman 2008). Vrba and Pakandl (2014) identified multiple Eimeria spp. infecting the turkey as Eimeria meleagridis, Eimeria dispersa, Eimeria gallopavonis, Eimeria meleagrimitis and Eimeria innocua and they indicated that Eimeria adenoeides is most probably a synonym for either $E$. meleagridis or E. gallopavonis. Moreover (Chapman 2008) reported that $E$. adenoeides, E. gallopavonis, and E. meleagrimitis are considered highly pathogenic, E. dispersa mildly pathogenic and E. meleagridis, E. innocua, and E. subrotunda non-pathogenic. The intestinal damage caused by coccidia is an essential predisposing factor for NE resulting in over growth of $C$. perfringens and toxin production (Assis et al., 2010).

Anticoccidial compounds should be highly effective against all developmental stages of Eimeria species, don't effect on the host immune response as well as have no residues in the tissues. In this respect, diclazuril is one of a series of benzenacetonitrile derivatives. The prophylactic anticoccidial efficacy of diclazuril in feed was studied in chickens by (Awaad et al., 2003), in addition to Sanaa et al. (2020) who reported that diclazuril is an effective anticoccidial drug in treatment of coccidiosis and $\mathrm{NE}$ in turkey.

The objective of this work is to investigate the hematological changes associated with experimental infection of C. perfringens and Eimeria species in turkeys with trial to illustrate their pathogenesis and find out the efficacy of diclazuril and amoxicillin on their control.

\section{MATERIALS AND METHODS}

\section{Experimental birds}

A total number of 40 one day old apparently healthy Balady turkey poults were used for this study; dropping of birds were examined to confirm the absence of coccidia using salt flotation (Permin and Hansen 1998). They were floor reared in separate units under hygienic measures. Turkeys were supplied with drinking water and starter feed (28\% protein) ad- libitum. They were divided randomly into 4 equally groups each of 10 birds. 


\section{The infective agents}

Eimeria spp: obtained from Animal Health Research Institute, Zagazig branch, and used by a dose 100.000 sporulated oocysts for each bird orally.

Clostridium perfringens: inoculums of $10^{8}$ CFU: obtained from Animal Health Research Institute, Zagazig branch, and used by a dose $2.5 \mathrm{ml}$ for each bird orally.

Preparation of Eimeria spp: oocysts were collected from the infected birds, scraping were made from the lesions and rinsed into potassium dichromate solution $(2.5 \%)$ to release the unsporulated oocysts then it stored at $4^{\circ} \mathrm{c}$. Oocysts must undergo sporulation before they are infective. The collected oocysts washed by distilled water 3-4 times and centrifuged on $3000 \mathrm{rpm}$ for 10 minutes to remove the potassium dichromate. The oocysts were counted using the hemocytometer method (Reid, 1978)

\section{Drugs}

Anticoccidial drugs: Diclazuril 10mg: Diclazuril (Pharma Swede Company) dose: $1 \mathrm{ml} / 2$ liter drinking water for two successive days.

Antibiotics: Amoxicillin antibiotic powder: Amoxitryl (Pharma Swede Company) dose: $20 \mathrm{mg} / \mathrm{kg}$ body for 3 successive days

\section{Experimental design}

40 one day old Balady turkey poults were used. Turkeys were divided randomly into 4 equal groups. Turkeys of group (1) remain as non- infected non- treated (negative control). Group (2) was infected orally at 21day old with 100.000 sporulated oocysts of Eimeria spp (Dalloul et al., 2003). Group (3) was infected orally at day $28^{\text {th }}$ day old with $2.5 \mathrm{ml}$ of $10^{8} \mathrm{CFU} C$. perfringens inoculums (Ferdoush et al., 2014). Group (4) was infected with both Eimeria spp ( $21^{\text {th }}$ day old) and $C$. perfringens $\left(28^{\text {th }}\right.$ day old).
Group $(2,3,4)$ were treated with diclazuril, amoxicillin and (diclazuril+amoxixillin) respectively and after the appearance of symptoms.

\section{Sampling}

Blood samples: two blood samples from five poults in each group were collected after the appearance of symptoms and one week after the treatment from the wing vein under aseptic conditions using a sterilized syrings, one on EDTA anticoagulant for hematological examination and the other on heparin anticoagulant osmotic fragility test.

\section{Hematological studies:}

Erythrocyte counts were recorded using an improved Neubauer hemocytometer and Natt and Herrick solution as a special diluent for chicken blood as described by Harrison and Harrison (1986). The packed cell volume was estimated using micro hematocrit centrifuge as described by Coles (1986) Hemoglobin level was estimated using the cyanomethemoglobin colorimetric method after centrifugation according to Van Kampen and Zijlstra (1983). Mean corpuscular volume (MCV) and mean corpuscular hemoglobin concentration (MCHC) were calculated. Blood films were prepared, fixed using methyl alcohol, and stained by Giemsa for estimating the differential leukocyte count as described by Feldman et al. (2000).

Osmotic fragility test: was performed using Weitherman tube, $\mathrm{NaCl} 1 \%$ and distilled water by preparation of 12 tubes of hypotonic solution of saline started at 0.8 saline solution till 0.25 saline solution, then put one drop of heparinized blood to each tube and mixing it by inverting the tubes. Leave them for $20 \mathrm{~min}$. at room temperature then centrifugation at $1500 \mathrm{rpm}$ for $15 \mathrm{~min}$. then reading it against white background to detect the initial lysis (the first tube were the saline changed to red color) and the complete lysis (the last tube still have RBCc settled at the bottom) Miale (1982). 


\section{Statistical analysis}

The data in this study were statistically analyzed by one way anova (Tamhane and Dunlop 2000) using the MSTAT-C computer program. Results are presented as mean $\pm \mathrm{SE}$, and the statistical significance was set at $(\mathrm{P} \leq 0.05)$. The significance between groups represented by small letters and the highest value represented by (a) letter.

\section{RESULTS}

\section{Clinical signs, postmortem lesions:}

The clinical signs observed in infected groups (2, 3 and 4) were depression, ruffled feather, bloody diarrhea and growth retardation. With regard to morbidities and mortalities, the results showed that group (4) (mixed infection with coccidia and clostridium) had higher morbidity rate $(50 \%)$ and mortality higher $(50 \%)$ of birds than group (2) (challenged with coccidia) (50\%) morbidity and (40\%) mortality of birds, finally group (3) (challenged with clostridium perfringens only) (40\%) morbidity and (50\%) mortality. One week after treatment most of these symptoms in tested groups disappeared and no mortalities were observed.

\section{Hematological results}

Compared with normal control group (1), at the appearance of symptoms, there was a significant decrease $(\mathrm{P} \leq 0.05)$ in $\mathrm{RBCs}$ count, Hemoglobin content, and hematocrit with significant increase $(\mathrm{P} \leq 0.05)$ in the mean corpuscular volume in gp. (2, 3 and 4). Significant decrease in mean corpuscular hemoglobin concentration (MCHC) in groups (2 and 4) which revealed macrocytic hypochromic anemia in these groups and nonsignificant changes in MCHC in group (3) which revealed macrocytic normochromic anemia (Table 1). One week after treatment with amoxicillin and diclazuril, birds in groups (2, 3 and 4), showed nonsignificant changes in RBCs count, Hemoglobin content, and hematocrit value when compared with normal control group (Table 2). The platelets count showed significant increase in gp. (2 and 4) challenged with coccidia and ciccidia and chlostridia, with nonsignificant change in gp. (3) infected with cholestridia only (Table 1). After treatment the platelets count returned to normal in all groups (Table 2).

\section{Leukogram results}

The leukogram showed a significant increase in total leukocytic count and heterophil count in groups (3 and 4) with significant increase in the eosinophilic count in groups. (2 and 4) compared with normal control group. Group (4) only showed significant decrease in basophilic count. Nonsignificant changes were seen in lymphocytic and monocytic counts in all groups (Table 1). Nonsignificant changes in all examined leukogram parameters were seen in groups (2, 3 and 4) comparing to normal control gp. one week after treatment with amoxicillin, diclazuril and their combination respectively (Table 2). 
Table 1: Hematological changes of the control and tested groups (Mean $\pm S E)(n=5)$.

\begin{tabular}{|c|c|c|c|c|}
\hline $\begin{array}{c}\text { Groups } \\
\text { parametres }\end{array}$ & $\begin{array}{l}\text { Control } \\
\text { (1) }\end{array}$ & $\begin{array}{c}\text { Coccidia } \\
(2)\end{array}$ & $\begin{array}{c}\text { Clost } \\
(3)\end{array}$ & $\begin{array}{c}\text { Clost+coccidia } \\
\text { (4) }\end{array}$ \\
\hline RBCs count $\left(\times 10^{6}\right.$ cells $\left./ \mu \mathrm{l}\right)$ & $3.01 \pm .098^{\mathrm{a}}$ & $2.21 \pm 0.09^{\mathrm{d}}$ & $2.51 \pm 0.087^{\mathrm{bc}}$ & $2.44 \pm 0.01^{\mathrm{bcd}}$ \\
\hline Hemoglobin $(\mathrm{gm} \%)$ & $12.27 \pm 0.07^{\mathrm{a}}$ & $10.47 \pm 0.29^{\mathrm{bc}}$ & $11.00 \pm 0.20^{\mathrm{bcd}}$ & $10.4 \pm 0.2^{\mathrm{d}}$ \\
\hline PCV \% & $31.79 \pm 0.1^{\mathrm{a}}$ & $28.87 \pm 0.26^{\mathrm{b}}$ & $29.87 \pm 1.14^{\mathrm{b}}$ & $28.72 \pm 0.16^{\mathrm{b}}$ \\
\hline$\overline{M C V ~ f l}$ & $105.66 \pm 3.78^{\mathrm{c}}$ & $130.63 \pm 0.94^{\mathrm{a}}$ & $119.05 \pm 0.83^{\mathrm{b}}$ & $117.7 \pm 0.21^{\mathrm{b}}$ \\
\hline $\mathrm{MCHC} \%$ & $38.59 \pm 0.29^{\mathrm{a}}$ & $36.27 \pm 0.89^{\mathrm{b}}$ & $36.82 \pm 0.78^{\mathrm{ab}}$ & $36.23 \pm 0.88^{\mathrm{b}}$ \\
\hline Platlets count $\left(\times 10^{3}\right.$ cells $\left./ \mu \mathrm{l}\right)$ & $28.67 \pm 1.67^{\mathrm{b}}$ & $44.67 \pm 2.9^{\mathrm{a}}$ & $33.33 \pm 1.33^{\mathrm{b}}$ & $46.67 \pm 2.91^{\mathrm{a}}$ \\
\hline WBCs count $\left(\times 10^{3}\right.$ cells $\left./ \mu \mathrm{l}\right)$ & $22.43 \pm 0.03^{\mathrm{b}}$ & $22.8 \pm 0.72^{\mathrm{b}}$ & $25.75 \pm 0.38^{\mathrm{a}}$ & $26.03 \pm 0.47^{\mathrm{a}}$ \\
\hline Lymphocyte count $\left(\times 10^{3}\right.$ cells $\left./ \mu \mathrm{l}\right)$ & $12.19 \pm 0.5^{b}$ & $13.31 \pm 0.36^{\mathrm{ab}}$ & $13.41 \pm 0.21^{\mathrm{ab}}$ & $13.37 \pm 0.49^{\mathrm{ab}}$ \\
\hline Monocyte count $\left(\times 10^{3}\right.$ cells $\left./ \mu \mathrm{l}\right)$ & $1.75 \pm 0.72$ & $1.3 \pm 0.12$ & $2.02 \pm 0.22$ & $1.53 \pm 0.38$ \\
\hline Heterophile count $\left(\times 10^{3}\right.$ cells $\left./ \mu \mathrm{l}\right)$ & $6.95 \pm 0.12^{b}$ & $5.22 \pm 1.7^{b}$ & $8.92 \pm 0.1^{\mathrm{a}}$ & $9.00 \pm 0.09^{\mathrm{a}}$ \\
\hline Eosinophile count $\left(\times 10^{3}\right.$ cells $\left./ \mu \mathrm{l}\right)$ & $0.37 \pm 0.08^{b}$ & $0.79 \pm 0.03^{\mathrm{a}}$ & $0.44 \pm 0.09^{\mathrm{b}}$ & $0.81 \pm 0.07^{\mathrm{a}}$ \\
\hline Basophile count $\left(\times 10^{3}\right.$ cells $\left./ \mu \mathrm{l}\right)$ & $1.07 \pm 0.12^{\mathrm{a}}$ & $1.04 \pm 0.1^{\mathrm{ab}}$ & $0.97 \pm 0.07^{\mathrm{ab}}$ & $0.84 \pm 0.11^{\mathrm{b}}$ \\
\hline $\begin{array}{l}\text { n: number of samples } \\
\text { TLC: Total leukocytic count } \\
\text { MCHC: Mean corpuscular he } \\
\text { Significant at } \mathrm{P} \leq 0.05\end{array}$ & Red blood ce & $\begin{array}{l}1 \text { count } \\
\text { ntration }\end{array}$ & \multicolumn{2}{|c|}{$\begin{array}{l}\text { CV: Packed cell volume } \\
\text { MCV: Mean corpuscular volume. } \\
\text { WBCs: White blood cell count }\end{array}$} \\
\hline
\end{tabular}

Table 2: Hematological changes of the control and tested groups (Mean $\pm S E)(n=5)$ After treatment.

\begin{tabular}{ccccc}
\hline $\begin{array}{c}\text { Groups } \\
\text { Parameters }\end{array}$ & $\begin{array}{c}\text { Control } \\
(\mathbf{1})\end{array}$ & $\begin{array}{c}\text { Coccidia } \\
(\mathbf{2})\end{array}$ & $\begin{array}{c}\text { Clost } \\
(\mathbf{3})\end{array}$ & $\begin{array}{c}\text { Clost+cocidia } \\
\mathbf{( 4 )}\end{array}$ \\
\hline RBCs count $\left(\times 10^{6} \mathrm{cells} / \mu \mathrm{l}\right)$ & $3.01 \pm .098$ & $2.83 \pm 0.13$ & $2.99 \pm 0.04$ & $2.89 \pm 0.047$ \\
\hline Hemoglobin $(\mathrm{gm} \%)$ & $12.27 \pm 0.07$ & $11.87 \pm 0.43$ & $11.33 \pm 0.35$ & $11.67 \pm 0.27$ \\
\hline PCV \% & $31.79 \pm 0.1$ & $30.59 \pm 0.61$ & $30.58 \pm 0.44$ & $30.15 \pm 0.49$ \\
\hline MCV fl & $105.66 \pm 3.78$ & $108.1 \pm 4.3$ & $102.27 \pm 0.29$ & $104.26 \pm 3.37$ \\
\hline MCHC \% & $38.59 \pm 0.29$ & $38.79 \pm 2.26$ & $37.05 \pm 0.74$ & $38.68 \pm 0.47$ \\
\hline Platlets count $\left(\times 10^{3} \mathrm{cells} / \mu \mathrm{l}\right)$ & $30.02 \pm 2.1$ & $30.41 \pm 1.8$ & $32.30 \pm 2.06$ & $34.67 \pm 1.33$ \\
\hline WBCs count $\left(\times 10^{3} \mathrm{cells} / \mu \mathrm{l}\right)$ & $22.43 \pm 0.03$ & $22.18 \pm 0.19$ & $23.67 \pm 0.18$ & $24.0 \pm 0.61$ \\
\hline Lymphocyte count $\left(\times 10^{3} \mathrm{cells} / \mu \mathrm{l}\right)$ & $12.19 \pm 0.5$ & $13.04 \pm 0.23$ & $12.63 \pm 0.15$ & $13.45 \pm 0.37$ \\
\hline Monocyte count $\left(\times 10^{3} \mathrm{cells} / \mu \mathrm{l}\right)$ & $1.75 \pm 0.72$ & $1.4 \pm 0.10$ & $1.54 \pm 0.26$ & $1.9 \pm 0.31$ \\
\hline Heterophile count $\left(\times 10^{3} \mathrm{cells} / \mu \mathrm{l}\right)$ & $6.95 \pm 0.12$ & $6.92 \pm 0.06$ & $7.87 \pm 0.04$ & $7.18 \pm 0.11$ \\
\hline Eosinophile count $\left(\times 10^{3} \mathrm{cells} / \mu \mathrm{l}\right)$ & $0.37 \pm 0.08$ & $0.41 \pm 0.09$ & $0.51 \pm 0.14$ & $0.46 \pm 0.1$ \\
\hline Basophile count $\left(\times 10^{3} \mathrm{cells} / \mu \mathrm{l}\right)$ & $1.07 \pm 0.12$ & $1.12 \pm 0.03$ & $1.11 \pm 0.08$ & $1.07 \pm 0.14$ \\
\hline
\end{tabular}

n: number of samples RBCs: Red blood cell count

TLC: Total leukocytic count

MCHC: Mean corpuscular hemoglobin concentration Significant at $\mathrm{P} \leq 0.05$

\section{RBCs osmotic fragility results}

The RBCs osmotic fragility, at the appearance of symptoms, there was a significant increase in in gps. (3 and 4) represented by initial lysis at $(0.59 \pm 0.04 \%)$ saline conc. with complete lysis at $(0.32 \pm$ $0.02 \%$ ) saline conc. in group (3) and initial
PCV: Packed cell volume

MCV: Mean corpuscular volume.

WBCs: White blood cell count lysis at $(0.64 \pm 0.06 \%)$ saline conc. with complete lysis at $(0.34 \pm 0.02 \%)$ saline conc. in gp. (4). Gp. (2) showed nonsignificant changes Fig. (1). One week after treatment the RBCs osmotic fragility showed non significant changes in all gps. Fig. (2). 


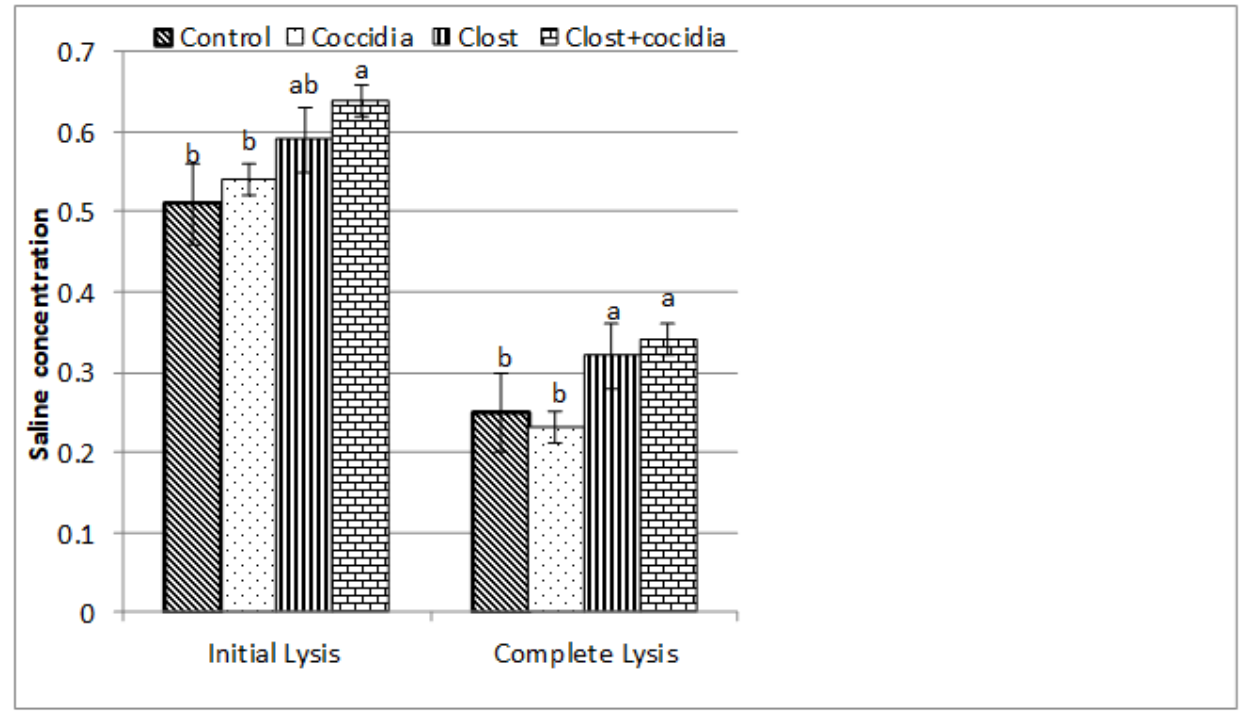

Fig. (1): Osmotic fragility test of the control and tested groups (Mean $\pm S E)(n=5)$ at the appearance of symptoms.

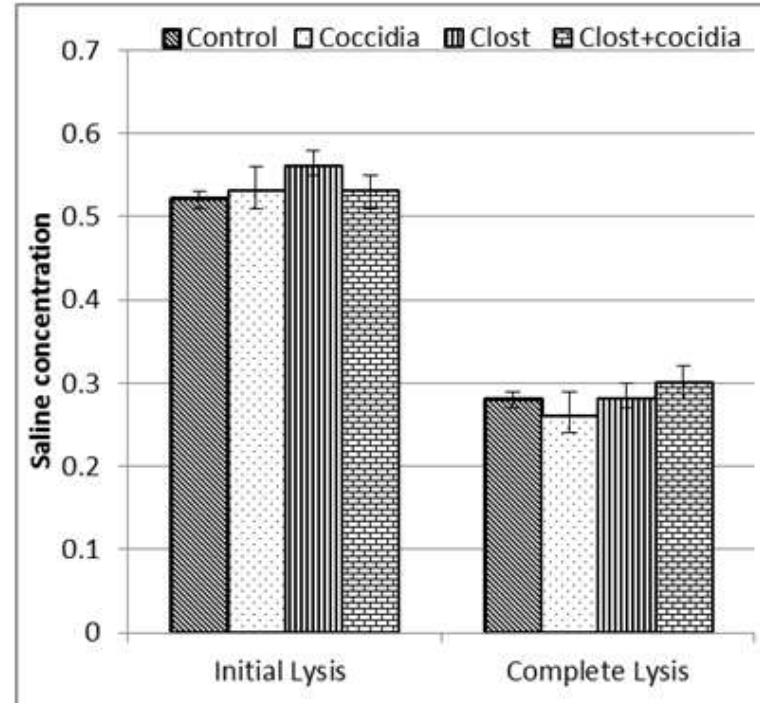

Fig. (2): Osmotic fragility test of the control and tested groups (Mean \pm SE) $(n=5)$ after treatment.

\section{DISCUSSION}

Intestinal coccidiosis and necrotic enteritis are implicated in severe economic losses in poultry industry. So the use of antimicrobials has been recognized as the most important turkey health issue. Prerana et al. (2018) found that amoxicillin was most effective against $(85.71 \%)$ of tested isolates. Other studies performed in the United States, China, and Norway had suggested that amoxicillin is the most effective against C. perfringens infection in poultry (Lianco et al., 2012). In addition to that El-Banna et al. (2005) and El-Dakhly 
et al. (2006) who reported that diclazural in the drinking water was the best choice for treatment of Eimeria spp.

Regarding the hematological changes associated with coccidiosis and necrotic interitis, a significant decrease in RBCs count, $\mathrm{Hb}$ content, $\mathrm{PCV}$ and $\mathrm{MCHC}$ with a significant increase in the MCV were seen in gps. (2 and 4) at the appearance of symptoms indicate macrocytic hypochromic anemia and the nonsignificant change in MCHC in gp. (3) indicate macrocytic normochromic anemia, which may be hemorrhagic or hemolytic anemia, but the increase in platelets count gps. 2 and 4 experimentally infected with Coccidia and Coccidia and $C$. perfringens respectively may indicate hemorrhagic anemia due to coccidial infestation to the intestinal mucosa. On the other hand the increase in the RBCs osmotic fragility in gps. 3 and 4 represented by the increase in the saline concentration of the initial lysis and complete lysis may indicate hemolytic anemia.

This agrees with Soad Belih et al. (2015), Melkamu et al. (2018). In addition to Mohammed (2012) who mention that the decline in the blood components in coccidiosis may be due to the severe bleeding and tissue damage in the mucosa of duodenum originated from invasion of Eimeria tenella (Mohammed 2012). Moreover, Melkamu et al. (2018) reported that, this due to the severe bleeding and tissue damage in the mucosal surface of intestine occurred at acute stage of infection from the invasion of different Eimeria spp.

The hemolytic anemia in gps. 3 and 4 infected with $C$. perfringens and Eimeria spp. and $C$. perfringens respectively may be due to liberation of large quantity of histamine as a result of the tissues injury which caused increased permeability of capillaries and venules allowing exudation of large quantities of fluid. The macrocytic normochromic anemia in gp. 3 infected with $C$. perfringens that agree with Soad Belih et al. (2015). This may be also due to Alpha toxins of the $C$. perfringens type A which are considered to be the major toxins involved in the disease pathogenesis. The activity of alpha toxin is lethal, necrotizing and hemolytic (Quinn et al., 2004; Fatmawati et al., 2013). The hemolytic activity may be due to binding of alpha toxin on the red cells receptor, which activates the signaling pathway in the cell, resulted in the hemolysis. Our finding is supported by Ombe et al. (2006).

Regarding the leukogram, the heterophilic leukocytosis in birds of gps. 3 and 4 may be due to bacterial infection but the eosinophilia in gp. 2 and 4 may be due to the parasitic investigation by the Eimeria spp. as mentioned by Melkamu et al. (2018). This was previously reported by Feldman et al. (2000) who mentioned that heterophilia is frequently observed with tissue damage induced by inflammation or bacterial infection, but eosinophilia in birds is commonly observed with parasitism. Tully et al. (2000) reported that leukocytosis and hetrophilia often indicate presence of infection or cellular damage and the same obesrved by Coles (1997), who also mentioned that an increase in the eosinophil count in avian blood samples indicate parasitic infection. The heterophils infiltration increase immediately after any infection as a first line of defence followed by increase in eosinophil concentration as a response to parasitic infection (Wakenell, 2010). Basopenia in gp. (4) may be of limited clinical importance in avian spp. as in other spp. as reported by Feldman et al. (2000). The Nonsignificant changes lymphocytic and monocytic counts in this study disagree with Melkamu et al. (2018) who observed increased numbers 
of lymphocytes on broilers infected by $C$. perfringens and E. tenella, in both infections.

One week after treatment with diclazuril, amoxicillin and their combination in gps 2,3 and 4 respectively showed improvement of the blood picture, whrer hemogram, RBCs osmotic fragility in addition to leukogram as total and differential leukocytic counts were significantly unnchanged, these result agree with Sanaa et al. (2020) who treated coccidiosis and NE in turkey with diclazuril and amoxicillin, El-Banna et al. (2005) and El-Dakhly et al. (2006) who reported that diclazural in the drinking water was the best choice for use in treatment of Eimeria spp., Aboubakr and Elbadawy (2017) who used Amoxicillin in Controlling Clostridium perfringens infection in Broiler Chickens and Palmer (1976) who reported that Amoxicillin is a one of most effective $\beta$ lactam antibiotic.

\section{CONCLUSION}

The obtained data from this study differentiated between the type of anemia in cases of coccidiosis and Necrotic enteritis in turkey. It declared that coccidiosis produced hemorrhagic anemia, but $C$. perfringens infection caused hemolytic anemia and necrotic enteritis caused mixed type of hemorrhagic and hemolytic anemia. It also studied the changes in the leukogram associated with it. In addition to that, amoxicillin and diclazuril in therapiotic doses ameliorated the changes associated with coccidiosis and necrotic enteritis in turkey. We recommended that, the use of diclazuril and amoxicillin and good management are important for control and prevention of coccidiosis and necrotic enteritis in turkey.

\section{REFERENCES}

Aboubakr, M. and Elbadawy, M. (2017): Efficacy of Flagymox (Amoxicillin and Metronidazole combination) in controlling Clostridium perfringens infection in broiler chickens. World journal of pharmacy and pharmaceutical sciences. 6(1):80-95.

Assis, R.C.L.; Luns, F.D.; Beletti, M.E.; Assis, R.L.; Nasser, N.M.; Faria, E.S.M. and Cury, M.C. (2010): Histomorphometry and macroscopic intestinal lesions in broilers infected with Eimeria acervulina. Vet. Parasitol. 168: 185-189.

Awaad, M.H.; Afify, M.A.; Zouelfakar, SA.; Hilali, M.A. (2003): Anticoccidial efficacy of steroidal sapogenins (organic coccidiostate) in broiler chickens (semi-field and field trials). Egypt. Vet. Med. Soci. Parasitol. J., 1(1): 123-136.

Baumgartner, J. (2003): Antibiotic susceptibility, of bacteria associated with endodontic abcesses.J. Endod, Finland, 29(1): 44-47.

Chapman, H.D. (2008): Coccidiosis in the turkey, Avian Pathology. (37):3.

Coles, B.H. (1997): Avian Medicine and surgery 2nd ed. University press, Cambridge. UK

Coles, E.H. (1986): Veterinary Clinical Pathology. 4th Edition ed. Philadelphia: W.B. Saunders Co.

Dalloul, R.A.; Lillehoj, H.S.; Shellem, T.A. and Doerr, J.A. (2003): Enhancement mucosal immunity against Eimeria acervulinain broilers fed Lactobacillus-based probiotic. Poultry Sci., 82: 62-66

El-Banna, H.A.; El-Bahy, M.M.; ElZorba, H.Y. and El-Hady, M. (2005): Anticoccidial efficacy of drinking water soluble diclazuril on experimental and field coccidiosis in broiler chickens. J Vet Med A 
Physiol. Pathol. Clin. Med. 52(6): 287- 91.

El-Dakhly, K.H.M.; El-Sawah, A.A.; Shalaby, A.A. and El-Nesr, K.H.A. (2006): The efficacy of Lactobacillus acidophilus and/or diclazuril for inhibition and control of Eimeria tenella infection in balady chicks.

Fasina, Y.O.; Newman, M.M.; Stough, J.M. and Liles, M.R. (2016): Effect of Clostridium perfringens infection and antibiotic administration on microbiota in the small intestine of broiler chickens. Poult. Sci. 95: 247-260.

Fatmawati, N.N.; Sakaguchi, Y.; Suzuki, T.; Oda, M.; Shimizu, K.; Yamamoto, $\quad$ Y.; Sakurai, J.; Matsushita, $O$. and Oguma, K. (2013): Phospholipase C produced by Clostridium botulinum types $\mathrm{C}$ and D: comparison of gene, enzymatic, and biological activities with those of Clostridium perfringens alpha-toxin. Acta Med Okayama. 67: 9-18.

Feldman, BF.; Zinkl, JG. and Jain, NC. (2000): Scham's Veterinary Hematology, 5th Ed., Lippincott Williams and Wilkins, Canada and London.

Ferdoush, M.; Rashid, M.; Dipti, M.; Roy, P.; Das, P. and Hossain, M. (2014): Effect of protein rich diet on experimental pathology of necrotic enteritis in broilers," Bangladesh Journal of Veterinary Medicine, (11):1.

Harrison, IG. and Harrison, LR. (1986): Clinical Avian Medicine and Surgery. London, Tokyo and Hong Kong: W B Saunders Co.

Lianco, L.A. and Nakano, V.; FERREIRA, A.J.P., and Avila-Campos, M.J. (2012): Toxinotyping and antimicrobial susceptibility of Clostridium perfringens isolated from broiler chickens with necrotic enteritis. International Journal of Microbiology Research. 4 (7)

McDevit, R.; Broker, J.; Acamovic, T. and Sparks, N. (2006): Necrotic enteritis; a continuning challenge for the poultry industry. World's Poult. Sci., 62: 221-247.

Melkamu, S.; Chanie, M. and Asrat, M. (2018): Haematological Changes Caused by Coccidiosis in Experimentally Infected Broiler Chickens. Int. J. Adv. Res. Biol. Sci. 5(5): 196-202. DOI: http://dx.doi.org/10.22192/ijarbs.20 18.05.05.020.

Miale, JB. (1982): Laboratory Medicine: Hematology, $6^{\text {th }}$ Ed, Mosby Co., St. Louis

Mohammed, K.A. (2012): Study of hematological and some biochemical values changing with administration of Salinomycin and Poultry star probiotics in broiler chickens challenged with Cocciodsis (Eimeria tenella) ALQadisiya J. Vet.Med.Sci. Vol./11 No./1

Ombe, B.M.H.; Kohda, T.; Mukamoto, M. and Kozaki. S. (2006): Purfication and sensitivity of Clostridium chauvoei hemolysin to various erythrocytes. Comparative Immunol., Microbiol. Infect. dis. 29: 263-268.

Osman, K.M. and Elhariri, M. (2013): Antibiotic resistance of Clostridium perfringens isolates from broiler chickens in Egypt. Rev. sci. tech. Off. int. Epiz., 32 (3), 841-850

Paiva, D. and McElroy, A. (2014): Necrotic enteritis: applications for the poultry industry. J. Appl. Poult. Res. 23: 557-566.

Palmer, G.; Buswell, J. and Yeoman, G. (1976): Amoxycillin: new veterinary penicillin. Vet. Rec., 99: 84-85

Parish, WE. (1961): Necrotic enteritis in the fowl. II. Examination of the 
causal Clostridium welchii. J Comp Pathol. 71: 394-404. doi: 10.1016/s0368-1742(61)80044-1.

Permin, A. and Hansen, J.W. (1998): The Epidemiology, Diagnosis and Control of Poultry Parasites. FAO Animal Health Manuals. Rome, Italy. $155 \mathrm{pp}$.

Prerana $R$. Shelke; Mrunalini $M$. Pawade; Prashant P. Mhase; Prajwalini V. Mehere and Jyotika D. Sangle (2018): Antibiotic Sensitivity and Histopathological Study of Clostridium perfringens Associated with Necrotic Enteritis in Poultry. Int.J.Curr.Microbiol. App.Sci. 7(11): 3159-3166.

Quinn, P.J.; Carter, M.A.; Markey, B. and Carte, G.R. (2004): Clin. Vet. Microb. Pp 191-208

Reid, W.M. (1978): Coccidiosis. In Diseases of Poultry, $7 \mathrm{t}$ hed., ed. Hofstad, M.S., Calnek, B.W., Helmboldt, C.F., Reid, W.M. and Yoder, H. W., Jr. Ames, IA: Lowa State University Press. 784-815.

Sanaa M. Salem; Doaa I.A. Mustafa; Rehab I. Hamed; Mona M. ElAzzouny and Nagwa Anwar (2020): Assessment of Pathological Changes of Mixed Infection of Coccidiosis and Necrotic Enteritis In Turkey. j.Egypt.vet.med.Assoc., 80(1)55-84.

Soad S. Belih; Zeinab M. Labib and Aml M. Ragab (2015): Role of Saltose Probiotic for the Control of the Experimental Infection of the Clostridium Perfringens and the Coccidia in Chickens. Alexandria Journal of Veterinary Sciences, 46: 20-41. ISSN, 1110-2047, www. alexjvs.com DOI: $10.5455 /$ ajvs. 188631.
Tamhane, A. and Dunlop, D. (2000): Statistic and Data Analysis from Elementary to Intermediate. USA: Upper Saddle River.

Timbermont, L.; Lanckriet, A.; Gholamiandehkordi, A.R.; Pasmans, F.; Martel, A. and Haesebrouck, F. (2009): Origin of Clostridium perfringens isolates determines the ability to induce necrotic enteritis in broilers, Comp. Immunol. Microbiol. Infect. Dis. 32: 503-512.

Timbermont, L.; Haesebrouck, F.; Ducatelle, $R$. and Van Immerseel, $F$. (2011): Necrotic enteritis in broilers. An Updated Review on the Pathogenesis. Avian Pathol.,.40, (4): 341-347.

Tully, TN.; Lawton, MPC. and Dorrestein, GM. (2000): Avian Medicine, 1st Ed, Butterworth Heinemann, Oxford.

Van Kampen, E.J. and Zijlstra, W.G. (1983): "Spectrophotometry of Hemoglobin and Hemoglobin Derivatives." In Advances in Clinical Chemistry, edited by A. L. Latner and Morton K. Schwartz, 199-257.

Vrba, V. and Pakandl, M. (2014): Coccidia of turkey: from isolation, characterisation and comparison to molecular phylogeny and molecular diagnostics. Int. J. Parasitol. 44(13):985-1000. doi: 10.1016/j.ijpara.2014.06.004.

Wakenell, P.S. (2010): Haematology of chickens and turkeys. In: Weiss, D.J. and Wardrop, K.J. (eds.).Veterinary haematology 6th ed. John Wiley \& Sons. amoxicillin and diclazuril Ames, Iowa, USA., Pp.957-967. 


\section{التغيرات الهيماتولوجيه المصاحبه للعدوى المشتركه بالكوكسيديا والالتهاب

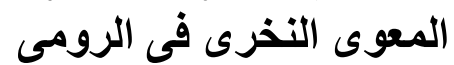

\section{دعاء ابراهيم /حمد مصطفى ، سناء محمد سالم}

E-mail: doaaibrahim706@gmail.com

Assiut University web-site: www.aun.edu.eg

يعتبر التهاب الامعاء النخرى من اهم المشاكل فى صناعه الدواجن عالميا ومحليا حيث تتسبب اصنابة كتاكيت

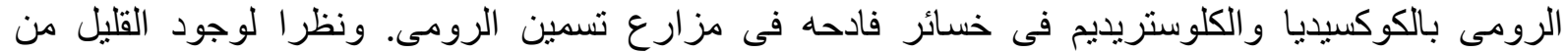

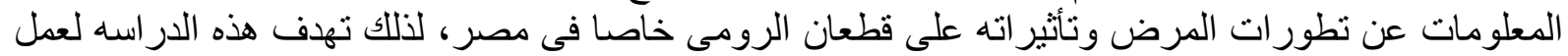

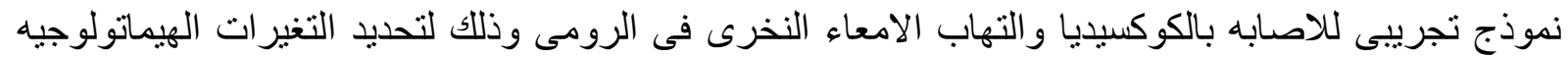
المصاحبه لهم ومحاولة معرفة كفاءة الاموكسى سيللين و الديكلازوريل في التغلب على فلى هذه التغيرات.

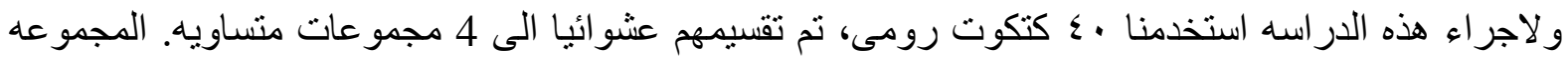

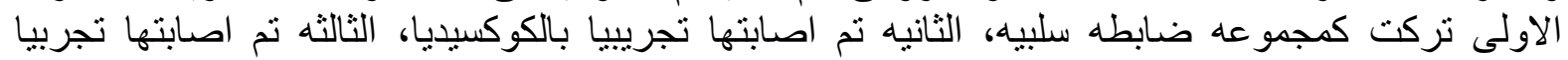

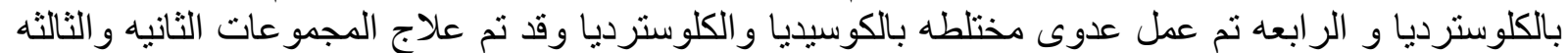

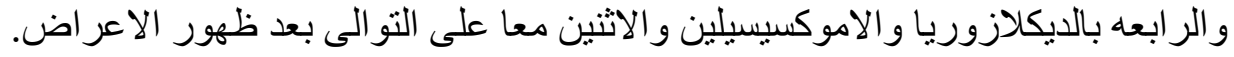

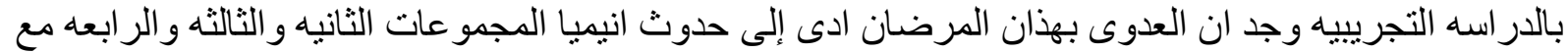

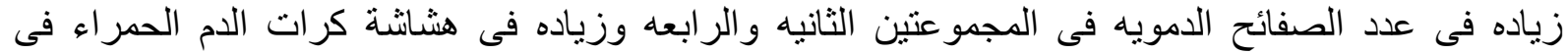

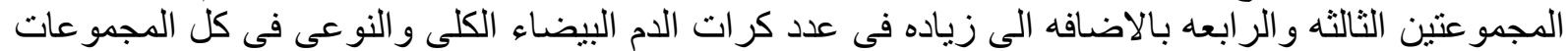

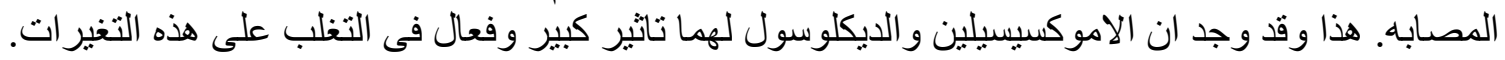

